\title{
Selective Bactericidal Activity of Divalent Metal Salts of Lauric Acid
}

\author{
Yoshiaki Yamamoto, ${ }^{\dagger}$ Toshiya Morikawa, ${ }^{\dagger}$ Takahiro Kawai, ${ }^{\dagger}$ and Yoshimune Nonomura*, ${ }^{\dagger}$ \\ ${ }^{\dagger}$ Department of Biochemical Engineering, Graduate School of Science and Engineering, Yamagata University, 4-3-16 Jonan, Yonezawa \\ 992-8510, Japan \\ ${ }^{\ddagger}$ Skin-Care Laboratories, Kao Corporation, CRIS Building, 2-1-3, Bunka, Sumida-ku, Tokyo 131-8501, Japan
}

\section{Supporting Information}

ABSTRACT: Bacteria play a crucial role in skin health. For example, Staphylococcus aureus and Propionibacterium acnes cause skin roughness and acne, whereas Staphylococcus epidermidis enhances innate barrier immunity. Therefore, controlling the bacterial flora is important in dermatology and cosmetic chemistry. In this study, the bactericidal activities of different metal salts of lauric acid were evaluated. The bactericidal behavior of the salts changed according to the type of metal ion. Specifically, the $\mathrm{Mg}$-, $\mathrm{Ca}-$, and $\mathrm{Mn}$-containing salts effectively sterilized only $S$. aureus and $P$. acnes. Their $\mathrm{Co}, \mathrm{Ni}$, and $\mathrm{Cu}$ salts sterilized all bacteria, including $S$. epidermidis, whereas the $\mathrm{Zn}$ salt proved ineffective. The $\mathrm{Cu}$ salt displayed the strongest bactericidal activity. Spin-trapping, detected using electron spin resonance, showed that this salt catalyzed the generation of hydroxyl radicals, which can
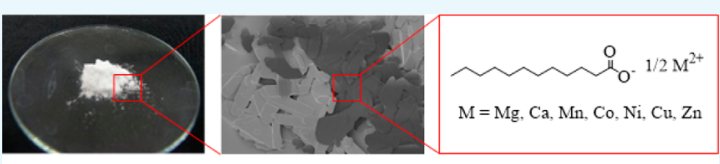

Selective bactericidal activity $=\mathrm{Mg}$, Ca and $\mathrm{Mn}$ salts
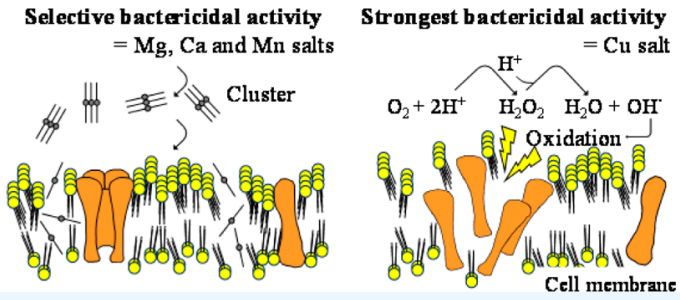
destroy bacterial cell membranes. These findings demonstrate that metal-ion selection is an important factor in the design of bactericidal agents for healthcare products.

\section{INTRODUCTION}

Bacteria, known as resident microbiota, live on the surface of human skin and play crucial roles in various skin conditions. The skin microbiota on healthy skin surfaces contains many forms of bacteria, such as Corynebacterium, Staphylococcus, and Propionibacteriaceae. ${ }^{1-3}$ Staphylococcal bacteria, including Staphylococcus aureus and Staphylococcus epidermidis, are present in the nasal cavity or in sebaceous glands. In addition, Propionibacteriaceae, such as Propionibacterium acnes, cause sebaceous conditions and acne-type symptoms. In particular, $S$. aureus causes inflammation of atopic dry skin as well as skin roughness and food poisoning. ${ }^{4,5}$ Conversely, S. epidermidis maintains epidermal health and enhances innate barrier immunity. ${ }^{6-8}$ Therefore, many dermatologists and cosmetic chemists have focused on the two harmful bacterial florae ( $S$. aureus and $P$. acnes) and the beneficial bacterial flora ( $S$. epidermidis) for the development of bactericidal agents to control the composition of the flora. ${ }^{9-12}$

In addition to acting as cleaning and frothing agents in cosmetics, fatty acids exhibit bactericidal activity. This activity has been evaluated against S. aureus, Bacillus Larvae, and Helicobacter pylori for fatty acids bearing 12-18 carbon long alkyl chains. ${ }^{13-17}$ Capric acid and lauric acid display a higher bactericidal activity than that of other saturated fatty acids. $^{13,18-20}$ According to Sun et al., lauric acid presents a minimum bactericidal concentration of $1 \mathrm{mM}$ against $H$. pylori. ${ }^{20}$ In addition, it exhibits a stronger bactericidal activity than that of other saturated fatty acids because its lipophilicity and water solubility promote its adsorption onto skin cell membranes. ${ }^{18}$
Some unsaturated fatty acids show a stronger bactericidal activity than that of their saturated analogues. $13,14,17,21-28$ Greenway et al. found that linoleic acid displays a higher bactericidal activity than that of stearic acid because of its ability to penetrate cell membranes. ${ }^{22}$ Desbois et al. reported that fatty acid molecules having cis-type double bonds adsorb easily onto the cell membrane and induce membrane disruption because of their bent structure. ${ }^{27,28}$ However, formulators need to pay attention to the instability of these unsaturated fatty acids against oxidation when employing them in cosmetic products. According to Villaverde et al., linoleic acid degrades into ketone-type compounds through peroxide formation. ${ }^{29}$

Furthermore, fatty acids have been shown to demonstrate selective bactericidal activity. Nakatsuji et al. found that lauric acid shows a stronger bactericidal activity against $S$. aureus than that against S. epidermidis. ${ }^{9}$ Moreover, Hsuan et al. reported that oleic acid preferentially kills $S$. aureus. ${ }^{30}$ Powdery divalent metal salts of fatty acids, or "soap scum", also display strong bactericidal activity, which is unexpected because of the low solubility of the salts. In particular, the calcium (Ca) salt of palmitoleic acid exhibits selective bactericidal activity against $S$. aureus and $P$. acnes. ${ }^{31}$ However, the relationship between the molecular structure and bactericidal activity of these divalent metal salts remains unclear. For example, an investigation into the effect of alkyl chain length on bactericidal activity revealed that the Ca salt of lauric acid exhibits a higher activity than that

Received: October 1, 2016

Accepted: December 27, 2016

Published: January 13, 2017 

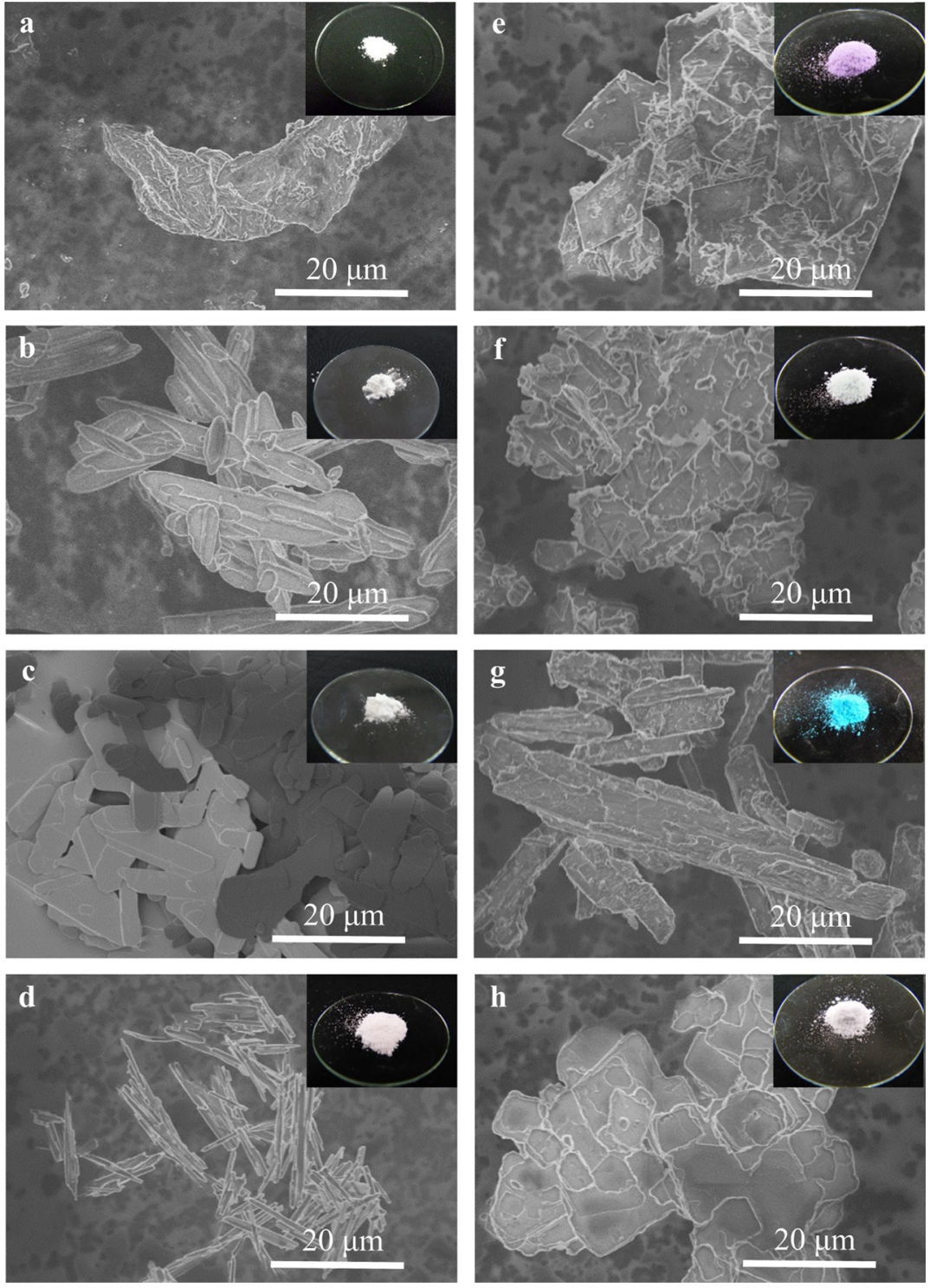

Figure 1. SEM images of lauric acid and its divalent metal salts. (a) Lauric acid, (b) Mg salt, (c) Ca salt, (d) Mn salt, (e) Co salt, (f) Ni salt, (g) Cu salt, (h) Zn salt.

of its palmitic acid analogue. ${ }^{31}$ Furthermore, the Ca salt of linoleic acid exhibits a stronger bactericidal activity than that of its stearic acid and oleic acid equivalents, demonstrating that the degree of unsaturation also affects the bactericidal activity. ${ }^{32}$

However, the effect of the counterions of fatty acid metal salts on bactericidal activity has not been investigated, whereas the bactericidal activity of metal ions alone has been extensively investigated. Nies measured the minimum inhibitory concentrations (MICs) of heavy metal ions against Escherichia coli and found that cobalt, nickel, copper, and zinc ions exhibit MICs of approximately $1.0 \mathrm{mM}$, whereas the manganese ion exhibits an MIC of approximately $20.0 \mathrm{mM} .^{33}$ In addition, several bactericidal mechanisms have been proposed for metal ions. For example, copper, zinc, and cobalt ions kill bacteria by producing radical oxygen, ${ }^{33-37}$ binding to cell membranes, ${ }^{38}$ and inhibiting enzyme activity, respectively. ${ }^{39}$

In this study, the effect of metal ions on the bactericidal activity of divalent metal salts of fatty acids was evaluated. The investigation focused on the performance of salts of lauric acid, which have been shown to have strong bactericidal activity toward $S$. aureus, $S$. epidermidis, and $P$. acnes as well as high stability against oxygen and light. ${ }^{31}$ The metal ions selected included alkali earth metals (magnesium and calcium ions), transition metals (manganese, cobalt, nickel, and copper ions), and the representative element (zinc ion). In addition, we compared the activities of the free fatty acid and its metallic chlorides to show the bactericidal effects of metal ions.

\section{RESULTS}

Preparation, Morphology, and Crystal Structure of the Divalent Metal Salts of Lauric Acid. The divalent metal salts of lauric acid, which were obtained in yields higher than $90 \%$, exhibit fluidity and hydrophobicity. When $0.01 \mathrm{~g}$ of salt was added to $35 \mathrm{~g}$ of water in a $20.3 \mathrm{~mm}$ diameter screw-cap tube, powder particles floated on the water surface and remained suspended for more than a week. The powder retained its appearance and odor after being stored for more than 1 month at $25{ }^{\circ} \mathrm{C}$ and $50 \%$ relative humidity. In addition, certain powders present different colors. Specifically, Mn, Co, $\mathrm{Ni}$, and $\mathrm{Cu}$ salts appear pastel pink, purple, pistachio green, and 


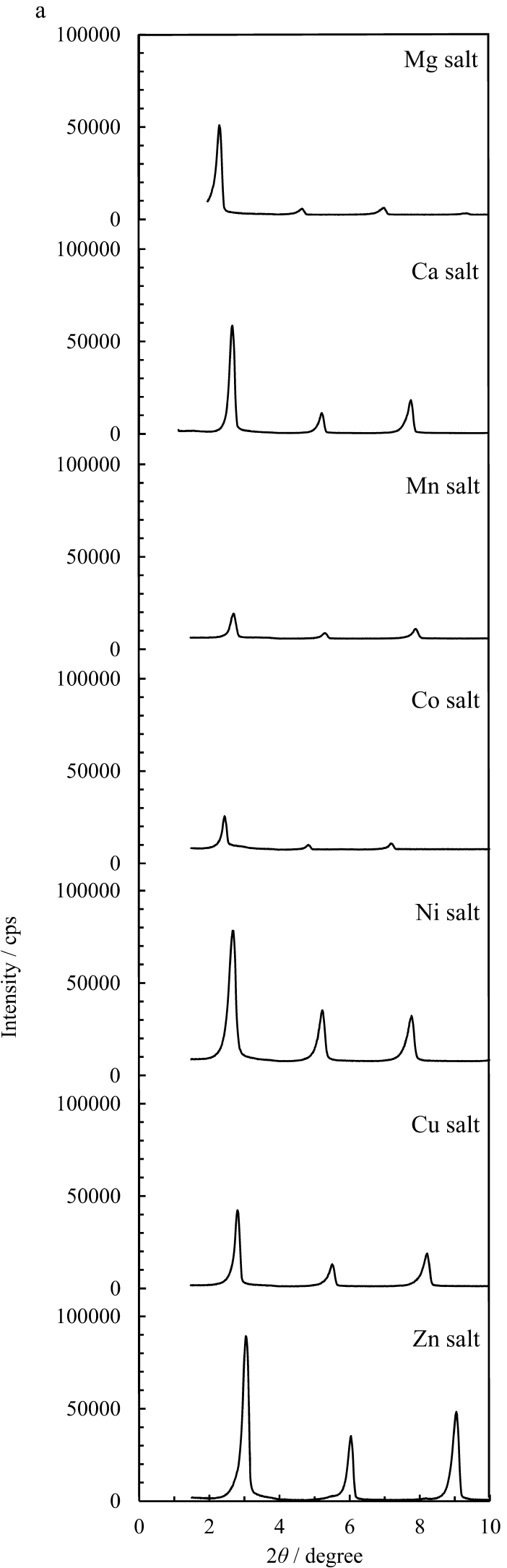

$\mathrm{b}$

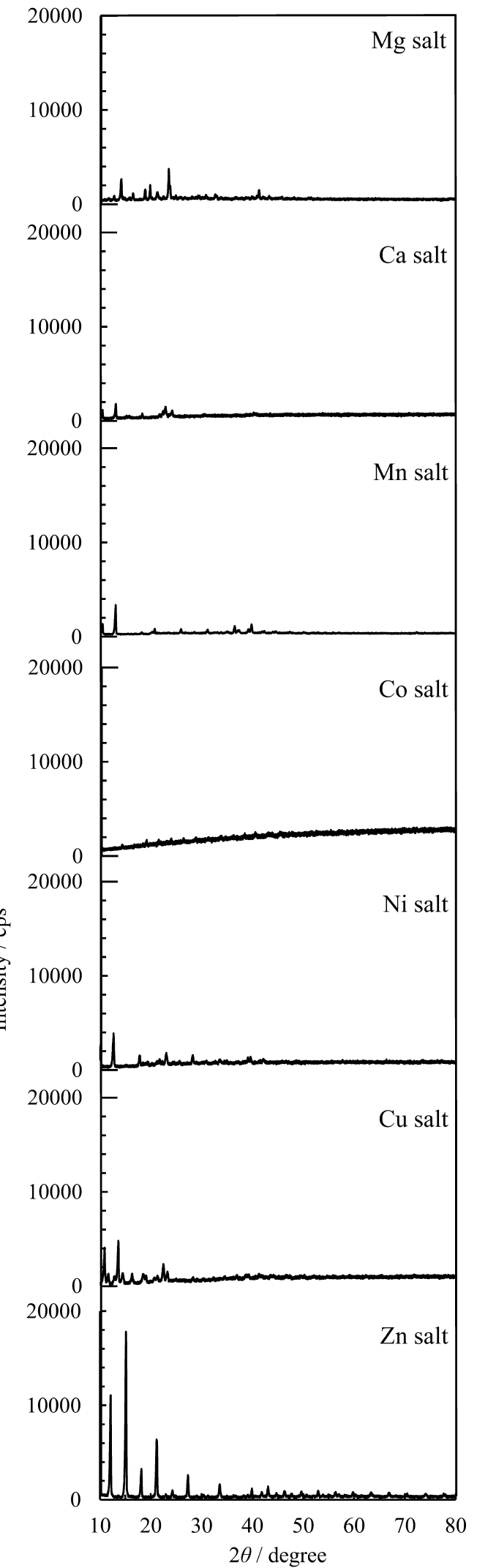

Figure 2. XRD patterns of divalent metal salts of lauric acid. (a) Low angle and (b) wide angle.

powder blue, respectively. In these transition metal salts, the vibrant colors result from $d-d$ transitions or charge transfer between metals and ligands. ${ }^{42,43}$ All $d$ orbitals are completely occupied in $\mathrm{Zn}$, resulting in a white salt. In contrast, $\mathrm{Mg}$ and $\mathrm{Ca}$ salts appear white because alkaline earth and alkali metal ions do not contain any $d$ electron. 

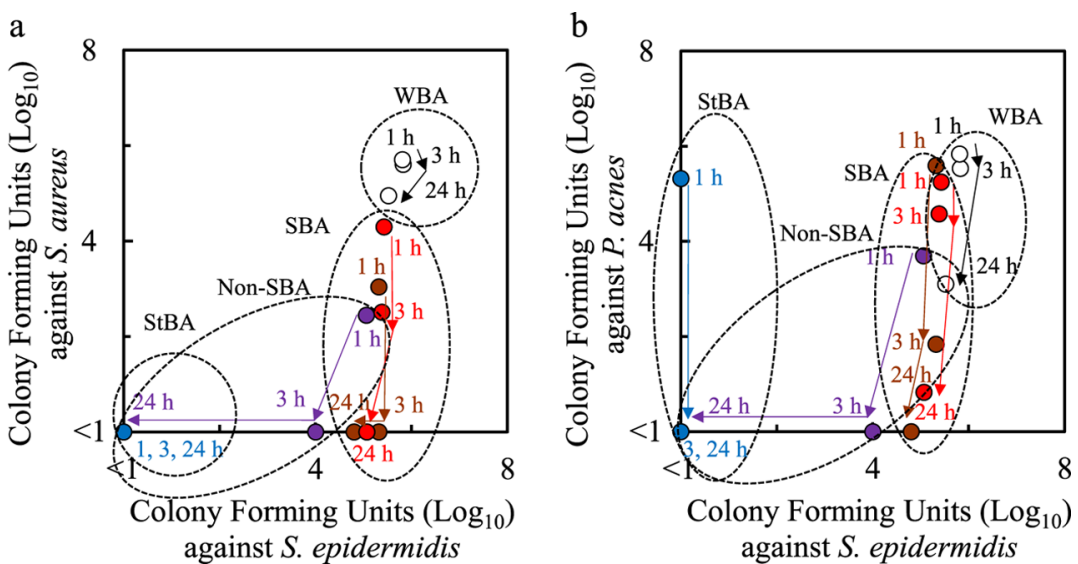

Figure 3. Bactericidal activities of lauric acid and its divalent metal salts. Temporal changes of colony-forming units (CFU) for $S$. aureus and $S$. epidermidis (a) and P. acnes and S. epidermidis (b). Brown circle: lauric acid; red circle: Ca salt; purple circle: Co salt; blue circle: Cu salt; white circle: Zn salt.
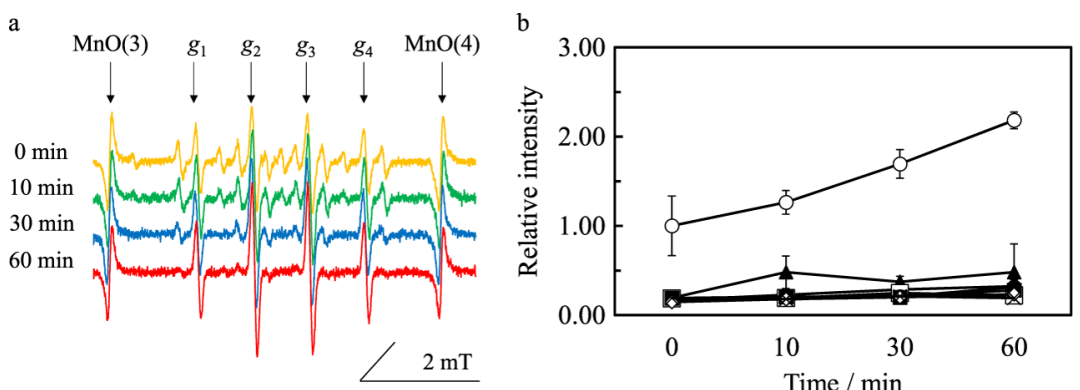

Figure 4. ESR spectra and temporal change of relative intensity for DMPO-OH. (a) ESR spectra of DMPO-OH in the system containing the Cu salt of lauric acid. (b) Temporal change of the relative intensity of the hydroxyl radical at $g_{2}$ by $\operatorname{MnO}(3)$. ( $\diamond:$ Lauric acid, $\downarrow: \mathrm{Mg}$ salt, $\triangle: \mathrm{Ca}$ salt, $\mathbf{\Delta}$ : Mn salt, $\square$ : Co salt, $\mathbf{\square}$ : Ni salt, O: Cu salt, $\bullet$ : Zn salt, $\times$ : DMPO).

Figure 1 shows scanning electron microscopy (SEM) images of the obtained divalent metal salts of lauric acid. The divalent metal salts consisted of platelike particles, ranging from several micrometers to several tens of micrometers in size. Corresponding X-ray diffraction (XRD) profiles are shown in Figure 2. For example, the $\mathrm{Mg}$ salt presents peaks at $2 \theta$ values of $2.3^{\circ}(d=38 \AA), 4.7^{\circ}(d=19 \AA)$, and $7.0^{\circ}(d=13 \AA)$, whereas its $\mathrm{Ca}$ analogue presents peaks at $2 \theta$ values of $2.7^{\circ}(d=$ $33 \AA), 5.2^{\circ}(d=17 \AA)$, and $7.8^{\circ}(d=11 \AA)$. These peaks are attributed to $\left(\begin{array}{lll}1 & 0 & 0\end{array}\right),\left(\begin{array}{lll}2 & 0 & 0\end{array}\right),\left(\begin{array}{lll}3 & 0 & 0\end{array}\right)$, and $\left(\begin{array}{lll}4 & 0 & 0\end{array}\right)$ diffractions of the bilayer structures, demonstrating that the salt particles adopt a lamellar crystalline structure.

Bactericidal Activity of the Divalent Metal Salts of Lauric Acid and Metallic Chlorides. In this study, the obtained divalent metal salts of lauric acid are categorized into four groups according to their bactericidal activity against $S$. aureus, S. epidermidis, and $P$. acnes. The selective bactericidal activity (SBA) group includes the salts that selectively kill $S$. aureus and $P$. acnes. The time-dependent bacterial counts recorded upon addition of lauric acid and its $\mathrm{Mg}, \mathrm{Ca}$, and $\mathrm{Mn}$ salts to three different bacteria are shown in Figure 3 and Table $S 1$. When lauric acid is added to $S$. aureus and $P$. acnes in phosphate buffer, the bacterial counts drop from $5.3 \pm 0.3 \log$ to less than $1 \log \mathrm{CFU} \mathrm{mL} \mathrm{m}^{-1}$ after 3 and $24 \mathrm{~h}$, respectively. In contrast, upon addition of lauric acid to $S$. epidermidis, the count does not change and remains at $4.8 \pm 0.0 \log \mathrm{CFU} \mathrm{mL} \mathrm{m}^{-1}$ after $24 \mathrm{~h}$. Similarly, when the $\mathrm{Mg}$ salt is added to $S$. aureus or $P$. acnes in phosphate buffer, the bacterial count decreases from $5.6 \pm 0.2 \log$ to less than $1 \log \mathrm{CFU} \mathrm{mL} \mathrm{m}^{-1}$ in $24 \mathrm{~h}$. However, the $\mathrm{Mg}$ salt does not affect the count of $S$. epidermidis (4.1 \pm $0.1 \log \mathrm{CFU} \mathrm{mL} \mathrm{m}^{-1}$ ) at $24 \mathrm{~h}$. When the Ca salt is added to $S$. aureus in phosphate buffer, the bacterial count drops to below $1 \log$ CFU mL $\mathrm{mL}^{-1}$ in $24 \mathrm{~h}$. In contrast, the counts of $P$. acnes and S. epidermidis remain at $0.8 \pm 1.4$ and $5.1 \pm 0.3 \log \mathrm{CFU} \mathrm{mL}{ }^{-1}$, respectively, in the presence of the Ca salt. The addition of the Mn salt to $S$. aureus and $P$. acnes in phosphate buffer reduces the bacterial counts from $5.8 \pm 0.2 \log$ to less than $1 \log C F U \mathrm{~mL}^{-1}$ after 1 and $3 \mathrm{~h}$, respectively. However, it does not impact $S$. epidermidis, which retains a count of $5.4 \pm 0.4 \log \mathrm{CFU} \mathrm{mL} \mathrm{m}^{-1}$ after $24 \mathrm{~h}$. These results indicate the selective bactericidal activity of the $\mathrm{Mg}, \mathrm{Ca}$, and $\mathrm{Mn}$ salts.

The non-selective bactericidal activity (non-SBA) group contains the salts that gradually sterilize all bacteria. The timedependent bacterial counts upon addition of the $\mathrm{Co}$ and $\mathrm{Ni}$ salts to three different bacteria are shown in Figure 3 and Table S1. When added to $S$. aureus, $S$. epidermidis, and $P$. acnes in phosphate buffer, the $\mathrm{Co}$ and $\mathrm{Ni}$ salts reduce the bacterial counts from $5.7 \pm 0.1 \log$ to less than $1 \log \mathrm{CFU} \mathrm{mL} \mathrm{m}^{-1}$ after 3, 24 , and $3 \mathrm{~h}$, respectively. Therefore, these salts exhibit bactericidal activity against all bacteria.

The strongest bactericidal activity (StBA) group contains only the $\mathrm{Cu}$ salt, which shows the highest activity. The timedependent bacterial counts obtained upon addition of the $\mathrm{Cu}$ salt to three different bacteria are shown in Figure 3 and Table $\mathrm{S} 1$. In the presence of the $\mathrm{Cu}$ salt, the $S$. aureus, S. epidermidis, and $P$. acnes counts in phosphate buffer decrease from $5.8 \pm$ $0.2 \log$ to less than $1 \log \mathrm{CFU} \mathrm{mL} \mathrm{mL}^{-1}$ after 1,1 , and $3 \mathrm{~h}$, 
respectively, demonstrating that this salt rapidly sterilizes all bacteria.

The weaker bactericidal activity (WBA) group contains only the $\mathrm{Zn}$ salt, which shows the weakest bactericidal activity. The time-dependent bacterial counts obtained upon addition of the $\mathrm{Zn}$ salt to three different bacteria are shown in Figure 3 and Table S1. In the presence of the Zn salt in phosphate buffer, the counts $S$. aureus, $S$. epidermidis, and $P$. acnes only decrease from $6.0 \pm 0.1$ to $5.0 \pm 0.2,5.5 \pm 0.1$, and $3.1 \pm 0.1 \log \mathrm{CFU} \mathrm{mL} \mathrm{m}^{-1}$ after $24 \mathrm{~h}$, respectively. Therefore, all counts remain above 3.0 $\log$ CFU mL $\mathrm{mL}^{-1}$, indicative of the weak bactericidal activity of the Zn salt.

The bactericidal data for the metallic chlorides are shown in Figure S1 and Table S2. The four metallic chlorides belong to the StBA or WBA group. Copper(II) chloride exhibits the strongest bactericidal activity, that is, all bacteria are sterilized by this salt over several hours. Conversely, cobalt(II) chloride hexahydrate, nickel(II) chloride hexahydrate, and zinc chloride exhibit weak bactericidal activity, that is, the bacterial counts of the three bacteria do not decrease over $3 \mathrm{~h}$.

Radical Formation in the Presence of Divalent Metal Salts of Lauric Acid. The time-dependent electron spin resonance (ESR) spectra of 5,5-dimethyl-1-pyrroline- $N$-oxide (DMPO)-OH upon addition of the $\mathrm{Cu}$ salt to a DMPO solution are shown in Figure 4a. The peaks at each end, that is, $\mathrm{MnO}(3)$ and $\mathrm{MnO}(4)$, are the third and fourth signals of the six standard signals for $\mathrm{MnO}$. These $\mathrm{MnO}$ peaks exhibit $g$ values of 2.033 and 1.981, respectively. The $g$ values of the four DMPO-OH peaks are 2.020, 2.011, 2.002, and 1.993 in the presence of the divalent metal salts of lauric acid. The timedependent relative intensity of $\mathrm{DMPO}-\mathrm{OH}$ at $g_{2}$ by $\mathrm{MnO}(3)$ is shown in Figure $4 \mathrm{~b}$. In addition, the hyperfine coupling constants present $A_{\mathrm{N}}$ and $A_{\mathrm{H}}$ values of 14.9 and 14.9, respectively, which are consistent with $\mathrm{DMPO}-\mathrm{OH}$ formation. ${ }^{44}$ The relative intensities obtained in the presence of the $\mathrm{Cu}$ salt are $1.00 \pm 0.33,1.26 \pm 0.13,1.69 \pm 0.16$, and $2.18 \pm$ 0.09 at $0,10,30$, and $60 \mathrm{~min}$, respectively. In contrast, the relative intensities obtained at $60 \mathrm{~min}$ in the presence of the $\mathrm{C} 12: 0$ fatty acid and its $\mathrm{Mg}, \mathrm{Ca}, \mathrm{Mn}, \mathrm{Co}, \mathrm{Ni}$, and $\mathrm{Zn}$ salts are $0.23 \pm 0.01,0.32 \pm 0.04,0.22 \pm 0.01,0.48 \pm 0.32,0.22 \pm 0.06$, $0.28 \pm 0.09$, and $0.31 \pm 0.09$, respectively. These ESR data indicate that hydroxyl radicals form only when the $\mathrm{Cu}$ salt is added to the DMPO solution.

\section{DISCUSSION}

Morphology and Crystal Structure of the Divalent Metal Salts of Lauric Acid. Here, we discuss the morphology and crystal structure of the divalent metal salts of lauric acid. All metal salts present platelike particles with a lamellar crystalline structure. The XRD profiles are similar to those obtained in previous experimental studies. ${ }^{31,32,40,45-47}$ These findings demonstrate that divalent metal salts of fatty acids, consisting of two straight-chain fatty acid molecules and a metal ion, form lamellar crystalline structures.

Sometimes, the addition of divalent metal ions induces the formation of vesicles or bilayer structures. ${ }^{48-50} \mathrm{Liu}$ et al. demonstrated that the critical micelle concentrations and aggregate morphologies of anionic sulfonate Gemini surfactants in aqueous solution are changed by their interaction with divalent metal counterions. ${ }^{50}$ This aggregation behavior can affect the bactericidal activity. ${ }^{51-53}$ Here, we evaluated the surface tension of aqueous solutions of divalent metal salts of lauric acid. As shown in Table S3, the surface tension of all aqueous solutions is $70-73 \mathrm{mN} \mathrm{m}^{-1}$, which is almost similar to that of water, that is, $72 \mathrm{mN} \mathrm{m}^{-1}$. ${ }^{54}$ These results suggest that fatty acid molecules do not form aggregation structures because there are very few dissolved molecules in the water phase.

Mechanism of Bactericidal Activity of the Divalent Metal Salts of Lauric Acid. A mechanism of bactericidal activity is proposed for each newly established bactericidal group. The bactericidal activity of divalent metal salts of fatty acids strongly depends on the (1) salt solubility, (2) metal-ion bactericidal activity, and (3) catalytic activity toward hydroxyl radical formation (Table 1 ). In the SBA group, the $\mathrm{Mg}$, $\mathrm{Ca}$, and

Table 1. Bactericidal Activities and Physical Properties of the Divalent Metal Salts of Lauric Acid ${ }^{a}$

\begin{tabular}{llcccc} 
sample & $\begin{array}{c}\text { bactericidal } \\
\text { ability of the } \\
\text { metal salts }\end{array}$ & $\begin{array}{c}\text { bactericidal } \\
\text { ability of the } \\
\text { metallic } \\
\text { chlorides }\end{array}$ & $\begin{array}{c}\text { solubility } \\
\left(\mathrm{g} \mathrm{L}^{-1}\right)\end{array}$ & $\begin{array}{c}\text { MIC of } \\
\text { metal } \\
\text { ions } \\
(\mathrm{mM})\end{array}$ & $\begin{array}{c}\text { radical } \\
\text { oxygen }\end{array}$ \\
$\begin{array}{c}\text { lauric } \\
\text { acid }\end{array}$ & SBA & $\mathrm{NT}$ & $0.55^{56}$ & & - \\
Mg salt & SBA & $\mathrm{NT}$ & $0.07^{55}$ & & - \\
Ca salt & SBA & $\mathrm{NT}$ & $0.019^{57}$ & & - \\
Mn salt & SBA & $\mathrm{NT}$ & $0.017^{58}$ & $20^{33}$ & - \\
Co salt & non-SBA & WBA & $0.011^{60}$ & $1.0^{33}$ & - \\
Ni salt & non-SBA & WBA & $0.022^{58}$ & $1.0^{33}$ & - \\
Cu salt & StBA & StBA & $0.00047^{58}$ & $1.0^{33}$ & + \\
Zn salt & WBA & WBA & insoluble & $1.0^{33}$ & - \\
$a_{+}$: active; & -: nonactive; NT: not tested. & & \\
\hline
\end{tabular}

Mn salts show similar bactericidal behaviors to those of lauric acid. We postulate that the most important factor for this fatty acid and its three salts is their solubilities. Lauric acid and its $\mathrm{Mg}, \mathrm{Ca}$, and $\mathrm{Mn}$ salts exhibit water solubilities of $0.55,0.07$, 0.019 , and $0.017 \mathrm{~g} \mathrm{~L}^{-1}$, respectively. ${ }^{55-58}$ However, lauric acid exhibits MIC values of $9.7 \times 10^{-4}, 3.9 \times 10^{-3}$, and $3.9 \times 10^{-3} \mathrm{~g}$ $\mathrm{L}^{-1}$ against $S$. aureus, $S$. epidermidis, and $P$. acnes, respectively. These MIC values are smaller than the solubilities of the divalent metal salts, suggesting that the concentration of lauric acid in an aqueous solution is enough to elicit bactericidal activity. ${ }^{33}$ Figure 5 a shows a mechanism for the bactericidal action of the SBA group. However, the mechanism that governs selectivity remains unclear. In general, the bactericidal mechanism of fatty acids is determined by three factors. ${ }^{22,26-28,59}$ The first factor is fluidization and destabilization of the cell membrane. The second and third factors are the conversion of DNA and inhibition of enzyme activity, respectively. The selectivity may be caused by differences in the composition of the lipids and proteins in the cell membrane, the DNA sequence, and the tertiary structure of the enzymes among the three bacteria.

The bactericidal mechanism of the non-SBA group is shown in Figure 5b. The Co and Ni salts exhibit water solubilities of 0.011 and $0.022 \mathrm{~g} \mathrm{~L}^{-1}$, respectively, which exceed the MIC of lauric acid. ${ }^{9,58,60}$ Moreover, the MIC of the metal ions is 1.0 $\mathrm{mM} .^{33}$ These data suggest that the bactericidal activity of the non-SBA-type salts arises from the fatty acid molecules and metal ions. The Co and Ni salts show a synergetic effect in their bactericidal activities, caused by both fatty acid molecules and metal ions; cobalt(II) chloride hexahydrate and nickel(II) chloride hexahydrate are in the WBA group. Therefore, these salts sterilize $S$. aureus, $S$. epidermidis, and $P$. acnes indiscriminately. 


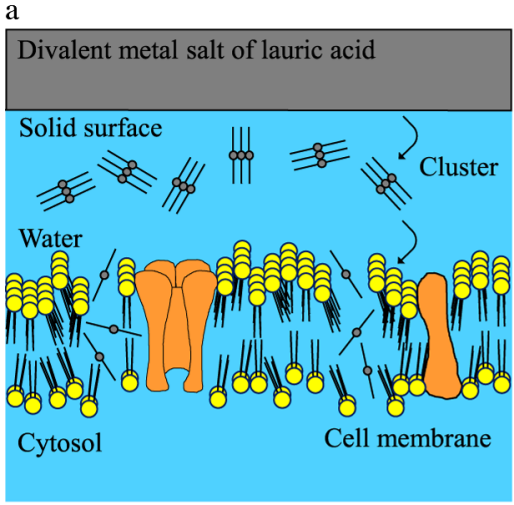

c

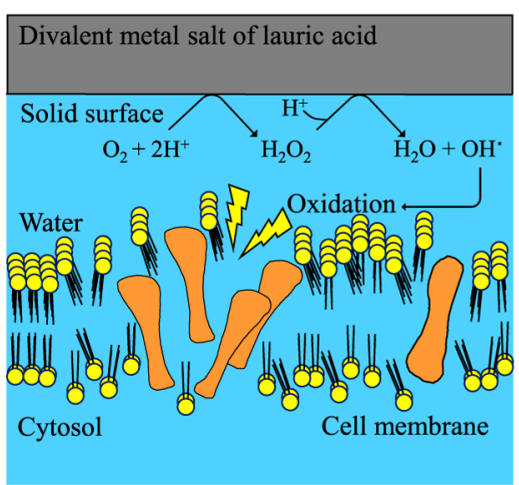

b

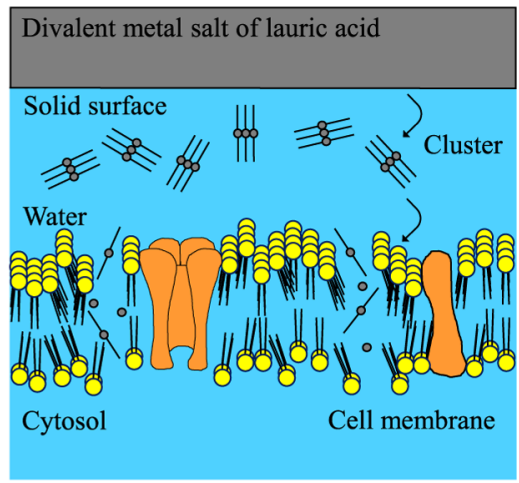

d

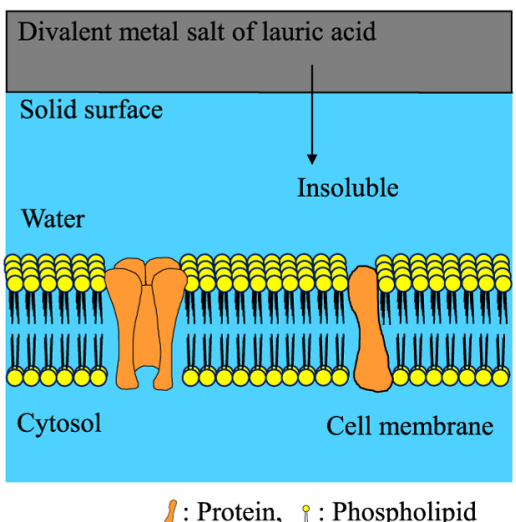

Figure 5. Bactericidal mechanisms of the divalent metal salts of lauric acid. (a) SBA group: Ma, Ca, and Mn salts; (b) non-SBA group: Co and Ni salts; (c) StBA group: Cu salt; and (d) WBA group: Zn salt.

Here, we discuss the reason for the strongest bactericidal activity of the $\mathrm{Cu}$ salt. Fatty acid molecules dissolved in water are not related to the biological activity of the $\mathrm{Cu}$ salt because the $\mathrm{Cu}$ salt displays a water solubility of $4.7 \times 10^{-4} \mathrm{~g} \mathrm{~L}^{-1}$, which is lower than the MIC values of the lauric acid against $S$. aureus, S. epidermidis, and P. acnes. ${ }^{58}$ We postulate that active oxygen molecules generated by the $\mathrm{Cu}$-salt-catalyzed reaction are responsible for the strong bactericidal activity (Figure 5c). Nies showed that the generation of radical oxygen and oxygenation of protein molecules occurred during the bactericidal process in the presence of $\mathrm{Cu}$ ions. ${ }^{33}$ Thurman et al. and Zhao et al. found that hydrogen peroxide, hydroxyl radicals, and superoxide are active molecules in this process. ${ }^{61,62}$ In the first step, the $\mathrm{Cu}^{2+}$ ions are reduced to $\mathrm{Cu}^{+}$by reaction with water molecules ${ }^{63}$

$$
2 \mathrm{Cu}^{2+}+\mathrm{H}_{2} \mathrm{O} \rightarrow 2 \mathrm{Cu}^{+}+2 \mathrm{H}^{+}+1 / 2 \mathrm{O}_{2}
$$

In the second and third steps, active oxygen molecules are generated by the Fenton-like reactions (reactions 2 and 3$)^{64}$

$$
\begin{aligned}
& 2 \mathrm{Cu}^{+}+\mathrm{O}_{2}+2 \mathrm{H}^{+} \rightarrow 2 \mathrm{Cu}^{2+}+\mathrm{H}_{2} \mathrm{O}_{2} \\
& \mathrm{Cu}^{+}+\mathrm{H}^{+}+\mathrm{H}_{2} \mathrm{O}_{2} \rightarrow \mathrm{H}_{2} \mathrm{O}+\mathrm{Cu}^{2+}+\mathrm{OH}^{\bullet}
\end{aligned}
$$

The generated hydrogen peroxide and hydroxyl radicals exhibit bactericidal activity by oxygenating the sugars and proteins present in the cell membrane. ${ }^{36}$ The bactericidal activity of copper(II) chloride dihydrate is similar to that of the $\mathrm{Cu}$ salt. However, we assume that the bactericidal mechanism of copper(II) chloride dehydrate is different from that of the $\mathrm{Cu}$ salt because no significant signals caused by active oxygen species are observed in the ESR profiles. We postulate that solubilized $\mathrm{Cu}^{2+}$ ions in water act against bacteria directly to impart bactericidal activity.

The bactericidal activity of the WBA group was examined. Zinc ions may show bactericidal activity by binding to the membranes of microorganisms. ${ }^{38}$ However, the $\mathrm{Zn}$ salt exhibits a water solubility that is too low to enable bactericidal activity of its components (Figure 5d). ${ }^{65}$ However, zinc chloride is slightly stronger than the $\mathrm{Zn}$ salt. These findings show that the potential bactericidal performance of this salt is difficult to achieve in the solid state.

\section{CONCLUSIONS}

The crystal structures and bactericidal activities of the divalent metal salts of lauric acid were established. All of the divalent metal salts were isolated as platelike lamellar crystalline particles measuring several micrometers to several tens of micrometers. They were classified into four groups according to their bactericidal behaviors. The SBA group, which included the $\mathrm{Mg}$, $\mathrm{Ca}$, and $\mathrm{Mn}$ salts, showed selective activity against $S$. aureus and $P$. acnes. In this case, the dissolved fatty acid molecules served as biologically active materials. The non-SBA group contained the Co and Ni salts, which sterilized all bacteria. Their biological activities stemmed from dissolved fatty acid molecules and metal ions. Next, the $\mathrm{Cu}$ salt exhibited the strongest bactericidal activity because it generated hydroxyl radicals. Finally, the $\mathrm{Zn}$ salt was classified into the WBA group because of its low solubility. These findings suggest that the nature of the metal ion plays an important role in the design of lipid-derived bactericidal agents. Controlled selectivity against bacteria is useful because technologies that regulate bacterial flora are 
expected to become central in the fields of cosmetics and healthcare products.

\section{EXPERIMENTAL SECTION}

Materials. Lauric acid $\left(\mathrm{CH}_{3}\left(\mathrm{CH}_{2}\right)_{10} \mathrm{COOH}\right)$, magnesium(II) chloride hexahydrate, manganese(II) chloride tetrahydrate, cobalt(II) chloride hexahydrate, nickel(II) chloride hexahydrate, copper(II) chloride dihydrate, zinc chloride, and phosphate buffer ( $\mathrm{pH}$ 6) were purchased from Wako Pure Chemical Industries Ltd. (Osaka, Japan). Calcium(II) chloride dihydrate was obtained from Sigma-Aldrich Co. LLC (St. Louis). Sodium hydroxide was purchased from Kanto Chemical Co. Inc. (Kanagawa, Japan). DMPO was purchased from Labotech Inc. (Tokyo, Japan).

Metal Salt Preparation. Several metal salts of lauric acid were prepared according to a reported method. ${ }^{40}$ As a representative example, the $\mathrm{Mg}$ salt was prepared as follows: lauric acid $(0.01 \mathrm{~mol})$ was mixed with water $(100 \mathrm{~mL})$, and sodium hydroxide $(0.01 \mathrm{~mol})$ in water $(2 \mathrm{~g})$ and magnesium chloride hexahydrate $(0.0055 \mathrm{~mol})$ in water $(5.0 \mathrm{~g})$ were added to the lauric acid aqueous solution. Then, the turbid solution was filtered to obtain a white precipitate, which was washed with water and acetone to remove any unreacted fatty acid and magnesium chloride and then dried under reduced pressure. In the above process, lauric acid was dissolved in suitable solvents for each metal salt. When we prepared the Ni salt, the fatty acid was dissolved in a $50 \mathrm{wt} \%$ aqueous acetone solution. In the case of the others salts ( $\mathrm{Ca}, \mathrm{Mn}, \mathrm{Co}, \mathrm{Cu}$, and $\mathrm{Zn}$ salts), the solvent was a $50 \mathrm{wt} \%$ aqueous ethanol solution.

If the $\mathrm{Cu}$ salt was assumed to be a nonhydrate comprising two fatty acid molecules and a copper ion, the elemental analysis results were consistent with the calculated values. Melting point: $>200{ }^{\circ} \mathrm{C}$; elemental analysis: C, $62.46 \%$; 9.80\%; $\mathrm{Cu}, 13.63 \%$. Composition of $\mathrm{Cu}\left(\mathrm{CH}_{3}\left(\mathrm{CH}_{2}\right)_{10} \mathrm{COO}\right)_{2}$ : C, $62.36 \% ; \mathrm{H}, 10.05 \% ; \mathrm{O}, 13.85 \% ; \mathrm{Cu}, 12.75 \%$. If the $\mathrm{Ca}, \mathrm{Mn}$, and $\mathrm{Zn}$ salts were assumed to be monohydrates containing two fatty acid molecules and a metal ion, the experimental elemental analysis results were consistent with the computed values. For the $\mathrm{Ca}$ salt, melting point: $174.0-179.3{ }^{\circ} \mathrm{C}$; elemental analysis: $\mathrm{C}, 62.93 \%$; $\mathrm{H}, 10.27 \%$; Ca, $8.60 \%$ (calcd for $\mathrm{Ca}\left(\mathrm{CH}_{3}\left(\mathrm{CH}_{2}\right)_{10} \mathrm{COO}\right)_{2} \cdot \mathrm{H}_{2} \mathrm{O}: \mathrm{C}, 63.06 \% ; \mathrm{H}, 10.05 \% ; \mathrm{O}$, 17.52\%; Ca, 8.78\%). For the Mn salt, melting point: $>200$ ${ }^{\circ} \mathrm{C}$; elemental analysis: C, 61.15\%; H, 9.97\%; Mn, $11.67 \%$ (calcd for $\mathrm{Mn}\left(\mathrm{CH}_{3}\left(\mathrm{CH}_{2}\right)_{10} \mathrm{COO}\right)_{2} \cdot \mathrm{H}_{2} \mathrm{O}: \mathrm{C}, 61.11 \% ; \mathrm{H}$, $10.28 \%$; O, 16.96\%; $\mathrm{Mn}, 11.65 \%)$. For the $\mathrm{Zn}$ salt, melting point: $125.0-126.0{ }^{\circ} \mathrm{C}$; elemental analysis: $\mathrm{C}, 60.67 \%$; $\mathrm{H}$, 9.55\%; $\mathrm{Zn}, 14.00 \%$ (calcd for $\mathrm{Zn}\left(\mathrm{CH}_{3}\left(\mathrm{CH}_{2}\right)_{10} \mathrm{COO}\right)_{2} \cdot \mathrm{H}_{2} \mathrm{O}: \mathrm{C}$, $59.79 \%$; 1 10.06\%; O, 16.59\%; Zn, 13.56\%). If the Co and $\mathrm{Ni}$ salts were assumed to be dihydrates comprising two fatty acid molecules and a metal ion, the elemental analysis results were consistent with the calculated values. For the Co salt, melting point: $>200{ }^{\circ} \mathrm{C}$; elemental analysis: $\mathrm{C}, 57.76 \%$;, $9.88 \%$; Co, $11.07 \%$ (calcd for $\mathrm{Co}\left(\mathrm{CH}_{3}\left(\mathrm{CH}_{2}\right)_{10} \mathrm{COO}\right)_{2} \cdot 2 \mathrm{H}_{2} \mathrm{O}: \mathrm{C}, 58.39 \%$; $\mathrm{H}, 10.23 \%$; O, $19.45 \%$; Co, $11.94 \%)$. For the Ni salt, melting point: $>200{ }^{\circ} \mathrm{C}$; elemental analysis: $\mathrm{C}, 58.46 \%$;, $10.09 \%$; $\mathrm{Ni}$, $10.60 \%$ (calcd for $\mathrm{Ni}\left(\mathrm{CH}_{3}\left(\mathrm{CH}_{2}\right)_{10} \mathrm{COO}\right)_{2} \cdot 2 \mathrm{H}_{2} \mathrm{O}: \mathrm{C}, 58.42 \%$; $\mathrm{H}, 10.23 \% ; \mathrm{O}, 19.46 \% ; \mathrm{Ni}, 11.89 \%)$. If the powder was assumed to be a trihydrate consisting of two fatty acid molecules and a magnesium ion, the experimental values from elemental analysis were consistent with the calculated values. Melting point: $147.7-150.3{ }^{\circ} \mathrm{C}$; elemental analysis: C, $60.26 \%$; $\mathrm{H}, 11.15 \% ; \mathrm{Mg}$, 5.46\% (calcd for $\mathrm{Mg}\left(\mathrm{CH}_{3}\left(\mathrm{CH}_{2}\right)_{10} \mathrm{COO}\right)_{2}$. $3 \mathrm{H}_{2} \mathrm{O}: \mathrm{C}, 60.42 \% ; \mathrm{H}, 11.01 \%$; O, 23.48\%; $\left.\mathrm{Mg}, 5.10 \%\right)$.
Analysis and Characterization. Individual metal contents were evaluated using an EDXL300 X-ray fluorescence spectrometer (Rigaku, Tokyo, Japan) for the Ca, Mn, Co, Ni, $\mathrm{Cu}$, and $\mathrm{Zn}$ salts. The magnesium content of the $\mathrm{Mg}$ salt was measured with a Z-5010 polarized Zeeman atomic absorption spectrophotometer (Hitachi, Tokyo, Japan). Melting points were determined using a melting-point apparatus (Bibby Scientific Ltd., Staffordshire, U.K.). SEM images were obtained using an SU8000 instrument (Hitachi High-Technologies Corp., Tokyo, Japan) at an electron beam accelerating voltage of $1 \mathrm{kV}$. XRD analyses were performed using a MiniFlex X-ray diffractometer (Rigaku, Tokyo, Japan) operating at $30 \mathrm{kV}$ and $15 \mathrm{~mA}$ to generate $\mathrm{Cu} \mathrm{K} \alpha$ radiation.

Bactericidal Activity. The bactericidal activities of the divalent metal salts of lauric acid were evaluated against $S$. aureus, $S$. epidermidis, and $P$. acnes. The divalent metal salts dispersed in 2 wt \% aqueous ethanol were added to $50 \mathrm{mM}$ phosphate buffer $(10 \mathrm{~mL}, \mathrm{pH} 6)$ containing the target bacteria. The metal salt concentration was $100 \mathrm{ppm}$. Bacterial counts per milliliter in the initial state amounted to $5.6 \pm 0.3 \log$ CFU. These dispersions were spread onto soybean-casein digest agar plates (with lectin and polysorbate 80), and the temporal change in the number of bacteria was monitored for $24 \mathrm{~h}$. $P$. acnes was cultivated under anaerobic conditions in an Anaeropack (Mitsubishi Gas Chemical Co., Inc., Tokyo, Japan) at an oxygen concentration below $0.1 \%$ and a carbon dioxide concentration exceeding $15 \%$. In contrast, S. aureus and $S$. epidermidis were cultivated under aerated conditions. In addition, the bactericidal activity of the metallic chlorides was assessed by the above method. The evaluated samples were cobalt(II) chloride hexahydrate, nickel(II) chloride hexahydrate, copper(II) chloride dihydrate, and zinc chloride. Three metallic chlorides, that is, magnesium(II) chloride hexahydrate, calcium(II) chloride dehydrate, and manganese(II) chloride tetrahydrate, were excluded from the evaluated samples because previous studies showed that they do not have bactericidal activity against several bacteria. ${ }^{33,41}$

ESR. The generation of hydroxyl radicals was detected by Xband ESR using an FR-30 spectrometer (ESR; JEOL Ltd., Tokyo, Japan). The divalent metal salts were added to $50 \mathrm{mM}$ phosphate buffer ( $\mathrm{pH} 6,45 \mu \mathrm{L})$ containing DMPO $(5 \mu \mathrm{L})$ and ethanol $(0.25 \mu \mathrm{L})$. The temporal change in the ESR signal was evaluated for $1 \mathrm{~h}$. The instrument specifications were set as follows: field: $335.300 \mathrm{mT}$; gain: 250.00 ; power: $4.000 \mathrm{~mW}$; sweep width: $5.000 \mathrm{mT}$; modulation width: $0.1 \mathrm{mT}$; sweep time: $2.0 \mathrm{~min}$; time constant: $0.03 \mathrm{~s}$; temperature: $25{ }^{\circ} \mathrm{C}$.

Determination of Surface Tension. Solutions of the metal salts of lauric acid were analyzed with a DM-501 contact angle meter (Kyowa Interface Science, Tokyo, Japan) at $25^{\circ} \mathrm{C}$ and $50 \%$ humidity using the pendant drop method, with a water droplet volume of ca. $0.5 \mu \mathrm{L}$. The divalent metal salts dispersed in 2 wt \% aqueous ethanol were added to water (10 $\mathrm{mL}$ ) and mixed over 3 days. The metal salt concentration was $0.1 \mathrm{~g} \mathrm{~L}^{-1}$.

\section{ASSOCIATED CONTENT}

\section{Supporting Information}

The Supporting Information is available free of charge on the ACS Publications website at DOI: 10.1021/acsomega.6b00279.

Bactericidal activities of lauric acid and its divalent metal salts (Table S1); bactericidal activities of metallic chlorides. Temporal changes in CFUs for S. aureus and 
S. epidermidis (a) and P. acnes and S. epidermidis (b) (Figure S1); bactericidal activities of the metallic chlorides (Table S2); surface tension of the solution of metal salts of lauric acid in a 2 wt \% aqueous solution (Table S3) (PDF)

\section{AUTHOR INFORMATION}

\section{Corresponding Author}

*E-mail: nonoy@yz.yamagata-u.ac.jp. Tel: +81-238-26-3164. Fax: +81-238-26-3406.

\section{ORCID}

Yoshimune Nonomura: 0000-0003-0461-124X

\section{Notes}

The authors declare no competing financial interest.

\section{ACKNOWLEDGMENTS}

This study was partly supported by the Yamagata University $\mathrm{YU}-\mathrm{COE}(\mathrm{C})$ program.

\section{REFERENCES}

(1) Grice, E. A.; Kong, H. H.; Conlan, S.; Deming, C. B.; Davis, J.; Young, A. C.; Bouffard, G. G.; Blakesley, R. W.; Murray, P. R.; Green, E. D.; Turner, M. L.; Segre, J. A. Topographical and Temporal Diversity of the Human Skin Microbiome. Science 2009, 324, 11901192.

(2) Lemon, K. P.; Klepac-Ceraj, V.; Schiffer, H. K.; Brodie, E. L.; Lynch, S. V.; Kolter, R. Comparative Analyses of the Bacterial Microbiota of the Human Nostril and Oropharynx. mBio 2010, 1, No. e00129.

(3) Oh, J.; Conlan, S.; Polley, E. C.; Segre, J. A.; Kong, H. H. Shifts in Human Skin and Nares Microbiota of Healthy Children and Adults. Genome Med. 2012, 4, 77.

(4) Novick, R. P. Autoinduction and Signal Transduction in the Regulation of Staphylococcal Virulence. Mol. Microbiol. 2003, 48, 1429-1449.

(5) Kobayashi, T.; Glatz, M.; Horiuchi, K.; Kawasaki, H.; Akiyama, H.; Kaplan, D. H.; Kong, H. H.; Amagai, M.; Nagao, K. Dysbiosis and Staphylococcus aureus Colonization Drives Inflammation in Atopic Dermatitis. Immunity 2015, 42, 756-766.

(6) Somerville, D. A. The Effect of Age on the Noemal Bacterial Flora of the Skin. Br. J. Dermatol. 1969, 81, 14-22.

(7) Somerville, D. A. The Normal Flora of the Skin in Different Age Groups. Br. J. Dermatol. 1969, 81, 248-258.

(8) Naik, S.; Bouladoux, N.; Linehan, J. L.; Han, S. J.; Harrison, O. J.; Wilhelm, C.; Conlan, S.; Himmelfarb, S.; Byrd, A. L.; Deming, C.; Quinones, M.; Brenchley, J. M.; Kong, H. H.; Tussiwand, R.; Murphy, K. M.; Merad, M.; Segre, J. A.; Belkaid, Y. Commensal-Dendritic-Cell Interaction Specifies a Unique Protective Skin Immune Signature. Nature 2015, 520, 104-108.

(9) Nakatsuji, T.; Kao, M. C.; Fang, J. Y.; Zouboulis, C. C.; Zhang, L.; Gallo, R. L.; Huang, C. M. Antimicrobial Property of Lauric Acid Against Propionibacterium acnes: Its Therapeutic Potential for Inflammatory Acne Vulgaris. J. Invest. Dermatol. 2009, 129, 24802488 .

(10) Yamaguchi, N.; Satoh-Yamaguchi, K.; Ono, M. In Vitro Evaluation of Antibacterial, Anticollagenase, and Antioxidant Activities of Hop Components (Humulus lupulus) Addressing Acne Vulgaris. Phytomedicine 2009, 16, 369-376.

(11) Wang, L.; Yang, X.; Qin, P.; Shan, F.; Ren, G. Flavonoid Composition, Antibacterial and Antioxidant Properties of Tartary Buckwheat Bran Extract. Ind. Crops Prod. 2013, 49, 312-317.

(12) Gao, C.; Guo, N.; Li, N.; Peng, X.; Wang, P.; Wang, W.; Luo, M.; Fu, Y. J. Investigation of Antibacterial Activity of Aspidin BB Against Propionibacterium acnes. Arch. Dermatol. Res. 2016, 308, 7986.
(13) Kabara, J. J.; Swieczkowski, D. M.; Conley, A. J.; Truant, J. P. Fatty Acids and Derivatives as Antimicrobial Agents. Antimicrob. Agents Chemother. 1972, 2, 23-28.

(14) Feldlaufer, M. F.; Knox, D. A.; Lusby, W. R.; Shimanuki, H. Antimicrobial Activity of Fatty Acids Against Bacillus larvae, the Causative Agent of American Foulbrood Disease. Apidologie 1993, 24, 95-99.

(15) Bergsson, G.; Steingrímsson, Ó.; Thormar, H. Bactericidal Effects of Fatty Acids and Monoglycerides on Helicobacter pylori. Int. J. Antimicrob. Agents 2002, 20, 258-262.

(16) Kelsey, J. A.; Bayles, K. W.; Shafii, B.; McGuire, M. A. Fatty Acids and Monoacylglycerols Inhibit Growth of Staphylococcus Aureus. Lipids 2006, 41, 951-961.

(17) Parsons, J. B.; Yao, J.; Frank, M. W.; Jackson, P.; Rock, C. O. Membrane Disruption by Antimicrobial Fatty Acids Releases LowMolecular-Weight Proteins from Staphylococcus aureus. J. Bacteriol. 2012, 194, 5294-5304.

(18) Galbraith, H.; Miller, T. B.; Paton, A. M.; Thompson, J. K. Antibacterial Activity of Long Chain Fatty Acids and the Reversal with Calcium, Magnesium, Ergocalciferol and Cholesterol. J. Appl. Bacteriol. 1971, 34, 803-813.

(19) Bergsson, G.; Arnfinnsson, J.; Steingrímsson, Ó.; Thormar, H. Killing of Gram-Positive Cocci by Fatty Acids and Monoglycerides. APMIS 2001, 109, 670-678.

(20) Sun, C. Q.; O'Connor, C. J.; Roberton, A. M. Antibacterial Actions of Fatty Acids and Monoglycerides Against Helicobacter pylori. FEMS Immunol. Med. Microbiol. 2003, 36, 9-17.

(21) Sheu, C. W.; Freese, E. Effects of Fatty Acids on Growth and Envelope Proteins of Bacillus subtilis. J. Bacteriol. 1972, 111, 516-524.

(22) Greenway, D. L. A.; Dyke, K. G. H. Mechanism of the Inhibitory Action of Linoleic Acid on the Growth of Staphylococcus aureus. J. Gen. Microbiol. 1979, 115, 233-245.

(23) Chamberlain, N. R; Mehrtens, B. G.; Xiong, Z.; Kapral, F. A.; Boardman, J. L.; Rearick, J. I. Correlation of Carotenoid Production, Decreased Membrane Fluidity, and Resistance to Oleic Acid Killing in Staphylococcus aureus 18Z. Infect. Immun. 1991, 59, 4332-4337.

(24) Stulnig, T. M.; Huber, J.; Leitinger, N.; Imre, E. M.; Angelisová, P.; Nowotny, P.; Waldhäusl, W. Polyunsaturated Eicosapentaenoic Acid Displaces Proteins from Membrane Rafts by Altering Raft Lipid Composition. J. Biol. Chem. 2001, 276, 37335-37340.

(25) Wille, J. J.; Kydonieus, A. Palmitoleic Acid Isomer (C16: 1 $\Delta 6)$ in Human Skin Sebum Is Effective Against Gram-Positive Bacteria. Skin Pharmacol. Appl. Skin Physiol. 2003, 16, 176-187.

(26) Zheng, C. J.; Yoo, J. S.; Lee, T. G.; Cho, H. Y.; Kim, Y. H.; Kim, W. G. Fatty Acid Synthesis Is a Target for Antibacterial Activity of Unsaturated Fatty Acids. FEBS Lett. 2005, 579, 5157-5162.

(27) Desbois, A. P.; Lebl, T.; Yan, L.; Smith, V. J. Isolation and Structural Characterisation of Two Antibacterial Free Fatty Acids from the Marine Diatom Phaeodactylum tricornutum. Appl. Microbiol. Biotechnol. 2008, 81, 755-764.

(28) Desbois, A. P.; Smith, V. J. Antibacterial Free Fatty Acids: Activities, Mechanisms of Action and Biotechnological Potential. Appl. Microbiol. Biotechnol. 2010, 85, 1629-1642.

(29) Villaverde, J. J.; Santos, S. A. O.; Simões, M. M. Q.; Neto, C. P.; Domingues, M. R. M.; Silvestre, A. J. D. Analysis of Linoleic Acid Hydroperoxides Generated by Biomimetic and Enzymatic Systems Through an Integrated Methodology. Ind. Crops Prod. 2011, 34, 1474-1481.

(30) Chao-Hsuan, C.; Wang, Y.; Nakatsuji, T.; Liu, Y. T.; Zouboulis, C. C.; Gallo, R. L.; Zhang, L.; Hsieh, M. F.; Huang, C. M. An Innate Bactericidal Oleic Acid Effective Against Skin Infection of MethicillinResistant Staphylococcus aureus: A Therapy Concordant with Evolutionary Medicine. J. Microbiol. Biotechnol. 2011, 21, 391-399.

(31) Yamamoto, Y.; Kawamura, Y.; Yamazaki, Y.; Kijima, T.; Morikawa, T.; Nonomura, Y. Palmitoleic Acid Calcium Salt: A Lubricant and Bactericidal Powder from Natural Lipids. J. Oleo Sci. 2015, 64, 283-288. 
(32) Yamamoto, Y.; Kijima, T.; Morikawa, T.; Nonomura, Y. Lubricant and Bactericidal Properties of Calcium Salts of Fatty Acids: Effect of Degree of Unsaturation. J. Oleo Sci. 2015, 64, 1095-1100.

(33) Nies, D. H. Microbial Heavy-Metal Resistance. Appl. Microbiol. Biotechnol. 1999, 51, 730-750.

(34) Repine, J. E.; Fox, R. B.; Berger, E. M. Hydrogen Peroxide Kills Staphylococcus aureus by Reacting with Staphylococcal Iron to Form Hydroxyl Radical. J. Biol. Chem. 1981, 256, 7094-7096.

(35) Ozawa, T.; Hanaki, A. The First ESR Spin-Trapping Evidence for the Formation of Hydroxyl Radical from the Reaction of Copper(II) Complex with Hydrogen Peroxide in Aqueous Solution. J. Chem. Soc., Chem. Commun. 1991, 5, 330-332.

(36) Kohanski, M. A.; Dwyer, D. J.; Hayete, B.; Lawrence, C. A.; Collins, J. J. A Common Mechanism of Cellular Death Induced by Bactericidal Antibiotics. Cell 2007, 130, 797-810.

(37) Santo, C. E.; Taudte, N.; Nies, D. H.; Grass, G. Contribution of Copper Ion Resistance to Survival of Escherichia Coli on Metallic Copper Surfaces. Appl. Environ. Microbiol. 2008, 74, 977-986.

(38) Atmaca, S.; Gul, K.; Cicek, R. The Effect of Zinc on Microbial Growth. Turkish J. Med. Sci. 1998, 28, 595-597.

(39) Kobayashi, M.; Shimizu, S. Metalloenzyme Nitrile Hydratase: Structure, Regulation, and Application to Biotechnology. Nat. Biotechnol. 1998, 16, 733-736.

(40) Vold, R. D.; Hattiangdi, G. S. Characterization of Heavy Metal Soaps by X-Ray Diffraction. Ind. Eng. Chem. 1949, 41, 2311-2320.

(41) Workentine, M. L.; Harrison, J. J.; Stenroos, P. U.; Ceri, H.; Turner, R. J. Pseudomonas fluorescens' View of the Periodic Table. Environ. Microbiol. 2008, 10, 238-250.

(42) Carlin, R. L. Transition Metal Complexes of Pyridine N-Oxide. J. Am. Chem. Soc. 1961, 83, 3773-3775.

(43) Lever, A. B. P. Charge Transfer Spectra of Transition Metal Complexes. J. Chem. Educ. 1974, 51, 612-616.

(44) Buettner, G. R. Spin Trapping: ESR Parameters of Spin Adducts. Free Radicals Biol. Med. 1987, 3, 259-303.

(45) Tyagi, B. K.; Varma, R. P.; Kumar, A. Investigations Into the Physicochemical Behaviour of Cobalt(II) Laurate. Phys. Chem. Liq. 1996, 31, 253-258.

(46) Barman, S.; Vasudevan, S. Melting of Saturated Fatty Acid Zinc Soaps. J. Phys. Chem. B 2006, 110, 22407-22414.

(47) Lisboa, F. S.; Gardolinski, J. E. F. C.; Cordeiro, C. S.; Wypych, F. Layered Metal Laurates as Active Catalysts in the Methyl/Ethyl Esterification Reactions of Lauric Acid. J. Braz. Chem. Soc. 2012, 23, $46-56$.

(48) Wang, J.; Song, A.; Jia, X.; Hao, J.; Liu, W.; Hoffmann, H. Two Routes to Vesicle Formation: Metal-Ligand Complexation and Ionic Interactions. J. Phys. Chem. B 2005, 109, 11126-11134.

(49) Tian, H.; Wang, D.; Xu, W.; Song, A.; Hao, J. Balance of Coordination and Hydrophobic Interaction in the Formation of Bilayers in Metal-Coordinated Surfactant Mixtures. Langmuir 2013, 29, 3538-3545.

(50) Liu, Z.; Cao, M.; Chen, Y.; Fan, Y.; Wang, D.; Xu, H.; Wang, Y. Interactions of Divalent and Trivalent Metal Counterions with Anionic Sulfonate Gemini Surfactant and Induced Aggregate Transitions in Aqueous Solution. J. Phys. Chem. B 2016, 120, 4102-4113.

(51) Cabral, J. P. S. Mode of Antibacterial Action of Dodine (Dodecylguanidine Monoacetate) in Pseudomonas syringae. Can. J. Microbiol. 1992, 38, 115-123.

(52) Martins, L. M. S.; Mamizuka, E. M.; Carmona-Ribeiro, A. M. Cationic Vesicles as Bactericides. Langmuir 1997, 13, 5583-5587.

(53) Tavano, L.; Infante, M. R.; Riya, M. A.; Pinazo, A.; Vinardell, M. P.; Mitjans, M.; Manresa, M. A.; Perez, L. Role of Aggregate Size in the Hemolytic and Antimicrobial Activity of Colloidal Solutions Based on Single and Gemini Surfactants from Arginine. Soft Matter 2013, 9, 306-319.

(54) Vargaftik, N. B.; Volkov, B. N.; Voljak, L. D. International Tables of the Surface Tension of Water. J. Phys. Chem. Ref. Data 1983, $12,817-820$.
(55) Jacobson, C. A.; Holmes, A. Solubility Data for Various Salts of Lauric, Myristic, Palmitic, and Stearic Acids. J. Biol. Chem. 1916, 25, $29-53$.

(56) Ralston, A. W.; Hoerr, C. W. The Solubilities of the Normal Saturated Fatty Acids. J. Org. Chem. 1942, 7, 546-555.

(57) Yoke, J. T. The Solubility of Calcium Soaps. J. Phys. Chem. 1958, 62, 753-755.

(58) Mauchauffee, S.; Meux, E.; Schneider, M. Determination of the Solubility Products in Water at $20^{\circ} \mathrm{C}$ of 32 Metallic Carboxylates. Ind. Eng. Chem. Res. 2008, 47, 7533-7537.

(59) Marcotte, L.; Barbeau, J.; Edwards, K.; Karlsson, G.; Lafleur, M. Influence of the Lipid Composition on the Membrane Affinity, and the Membrane-Perturbing Ability of Cetylpyridinium Chloride. Colloids Surf., A 2005, 266, 51-61.

(60) Malik, W. U.; Singh, B. P.; Jain, A. K. Solubility of Cobalt Laurate in Water and Non-Aqueous Solvents. Experientia 1967, 23, $346-347$.

(61) Thurman, R. B.; Gerba, C. P.; Bitton, G. The Molecular Mechanisms of Copper and Silver Ion Disinfection of Bacteria and Viruses. Crit. Rev. Environ. Control 1989, 18, 295-315.

(62) Zhao, Z. H.; Sakagami, Y.; Osaka, T. Toxicity of Hydrogen Peroxide Produced by Electroplated Coatings to Pathogenic Bacteria. Can. J. Microbiol. 1998, 44, 441-447.

(63) Kasai, P. H.; Blshop, R. J. Thermochemical Decomposition of Water Catalyzed by Zeolites. J. Phys. Chem. 1977, 81, 1527-1529.

(64) Zhi-Hu, G.; Yamaguchi, F.; Itoh, A.; Kitani, A.; Sasaki, K. Hydroxylation of Aromatic Ring in Corroding Metal Systems. Electrochim. Acta 1992, 37, 345-347.

(65) Khan, M. A.; Shah, S. S.; Ahmad, Z. Thermal Non-Oxidative Degradation of PVC and Stabilizing Action of Various Surfactants Salts of Fatty Acids. Iran. Polym. J. 1996, 5, 251-257. 